\title{
Konselor Sebaya dalam Keterbatasan Waktu Konselor Memberikan Layanan Bimbingan dan Konseling Di Era Pandemi Covid 19
}

\author{
Elia Firda Mufidah ${ }^{1}$, Afrida Widyastuti ${ }^{2}$ \\ ${ }^{1}$ Universitas PGRI Adi Buana Surabaya \\ ${ }^{2}$ SMPN 37 Surabaya
}

\begin{tabular}{|c|c|}
\hline Article Info & ABSTRACT \\
\hline Article history: & \multirow{5}{*}{$\begin{array}{l}\text { Aturan school from home membawa tantangan tersendiri untuk guru Bimbingan } \\
\text { dan Konseling. Guru Bimbingan dan Konseling dituntut agar tetap mampe } \\
\text { memberikan layanan bimbingan dan konseling secara maksimal. Salah satu } \\
\text { upaya yang bisa dimaksimalkan dengan cara memanfaatkan adanya konselor } \\
\text { sebaya. Penelitian ini bertujuan untuk melihat keberfungsian konselor sebaya di } \\
\text { sekolah selama masa pandemic covid 19. Penelitian ini menggunakan penelitian } \\
\text { kualitatif deskriptif. Hasil penelitian diperoleh kesimpulan bahwa konselor } \\
\text { sebaya mempermudah konselor dalam memberikan layanan kepada siswa. }\end{array}$} \\
\hline Received Jan 12 ${ }^{\text {th }}, 2021$ & \\
\hline Revised Feb $20^{\text {th }}, 2021$ & \\
\hline Accepted Apr $26^{\text {th }}, 2021$ & \\
\hline Keyword: & \\
\hline
\end{tabular}

Konselor sebaya

Covid 19

Keberfungsian

\author{
Corresponding Author: \\ Elia Firda Mufidah, \\ Universitas PGRI Adi Buana Surabaya \\ Email: eliafirda@unipasby.ac.id
}

\section{Introduction}

Bimbingan dan konseling merupakan salah satu bagian yang ada di sekolah. Bimbingan dan konseling menjadi salah satu hal yang berfungsi untuk mendukung optimalisasi perkembangan peserta didik. Optimalisasi tersebut dilakukan melalui bidang layanan-layanan yang ada dalam bimbingan dan konseling. Sesuai dengan Permendikbud 111 Tahun 2014 menjelaskan bidang layanan bimbingan dan konseling meliputi bidang layanan pribadi, sosial, belajar dan karier. Bidang layanan pribadi berfokus kepada pemahaman kekurangan serta kelebihan diri peserta didik. Bidang layanan social berfokus kepada pengembangan hubungan individu dengan orang lain. Bidang layanan belajar berfokus kepada optimalisasi belajar peserta didik agar mendapatkan hasil yang baik. Bidang layanan karier berfokus kepada perencanaan sampai pada pengambilan keputusan karier serta pengembangan karier. Bidang layanan tersebut memfasilitasi peserta didik untuk bisa optimal dalam mengembangkan dirinya.

Kondisi pandemic covid 19 memberikan dampak yang sangat besar terhadap proses pembelajaran. Pembelajaran dilakukan secara School from Home. SFH memberikan tantangan baru baik untuk guru, siswa ataupun wali murid atau orang tua. Guru dituntut untuk bisa terbuka dengan aplikasi-aplikasi digital untuk membantu proses tersampainya pembelajaran. Siswa dituntut untuk bisa lebih mandiri ketika belajar dan orang tua memiliki kewajiban baru untuk memantau dan menemani anaknya untuk mengikuti proses belajar 
mengajar. Hasil penelitian dari (Supriyanto et al., 2020)menemukan bahwa media asinkron dan media sinkron berbasis teknologi adalah alternatif utama untuk konseling online pelayanan selama wabah Covid-19. Penggunaan media asinkron dengan WhatsApp, Facebook, Instagram atau media sosial, serta media sinkron dengan Zoom, Webex, Google Meeting, atau Hangout, dapat membantu memecahkan masalah dan mengembangkan potensi siswa.

Implementasi layanan bimbingan dan konseling di era pandemic covid 19 masih belum bisa maksimal. Hal tersebut berdasarkan hasil penelitian (Rohmadi et al., 2021) menunjukkan bahwa layanan bimbingan dan konseling yang diberikan oleh Guru di masa pandemi Covid-19 belum optimal. Tanggapan siswa dalam menerima layanan berbeda-beda. Setiap subjek mengalami hambatan yang berbeda. Implmentasi bimbingan kelompok dalam layanan bimbingan dan konseling bisa membantu merubah pola piker siswa terkait pembelajaran daring selama pandemic covid 19 (Taufik, 2021)

Dari hasil wawancara guru Bimbingan dan Konseling di sekolah ini memaparkan bahwa ketika pandemic dan siswa harus mengikuti school from home permasalahan yang muncul adalah siswa sering absen atau tidak hadir dalam proses pembelajaran. Guru Bimbingan dan Konseling butuh untuk berkoordinasi dengan orang tua, tetapi ketika orang tua tidak bisa diajak untuk berkoordinasi maka disitu muncullah permasalahan yang dialami Guru Bimbingan dan Konseling. Oleh sebab itu guru Bimbingan dan Konseling membuat rencana untuk mebgoptimalkan konselor sebaya dalam membantu memantau kondisi yang dihadapi siswa ketika school from home.

Selain itu, guru Bimbingan dan konseling bisa memanfaatkan adanya konselor sebaya di sekolah. Konselor sebaya diharapkan bisa menjadi jembatan konselor dalam lebih mengetahui bagaimana kondisi psikis dan fisik siswa ketika School from Home. Hal tersebut terjadi karena koselor tidak bisa bertatap muka secara langsung dengan siswa. Berdasarkan hal tersebut, maka diperlukan solusi bagi kreatifitas konselor dalam memeberikan layanan bimbingan dan konseling di era pandemic covid 19, serta penting untuk dilakukan. Konselor harus bisa mengetahui apa yang terjadi di luar meja mereka yakni melalui pemberdayaan konselor sebaya.

\section{Method}

Metode penelitian deskriptif kualitatif. Menurut Sugiono (dalam (Saputra, 2020)) Penelitian kualitatif merupakan penelitian yang menempatkan instrument kunci, teknik dari pengumpulan data melalui penggabungan serta analisis data yang bersifat induktif. Penelitian kualitatif menghasilkan pengolahan data yang sedang diteliti. Dasar dari pemikiran penelitian ini yakni ingin mengetahui terkait fenomena alamiah bukan eksperimen maupun kondisi terkendali. Sehingga focus penelitian ini pada gambaran keberfungsian konselor sebaya di sekolah tempat penelitian.

Penelitian ini menggunakan observasi dan wawancara untuk pengumpulan data atau hasil penelitiannya. Informan dalam penelitian ini yakni 1 guru Bimbingan dan Konseling di SMPN 37 Surabaya. Observasi dilakukan selama 6 bulan (Januari 2020-Juni 2020) dengan mengikuti kegiatan guru Bimbingan dan Konseling ketika melibatkan konselor sebaya. Wawancara menggunakan pedoman wawancara meliputi : bagaimana layanan BK selama pandemic covid 19, apakah memiliki konselor sebaya di sekolah?, bagaimana implementasi layanan bk yang melibatkan konselor sebaya, dan bagaimana kebermanfaatan adanya konselor sebaya.

\section{Results and Discussions}

Peer counseling merupakan salah satu dukungan sosial. Hal ini terjadi karena peer counseling merupakan sebuah bentuk bantuan yang diberikan oleh teman sebaya dengan berbagai macam cara yang dilakukannya dalam aktivitasnya. Peer counseling merupakan salah satu upaya dalam berkomunikasi dan mendengarkan antar remaja untuk mengetahui permasalahan apa yang sedang terjadi (Carr, 1984 dalam (Geldard, 2005)). Konselor sebaya jika dikaji bisa masuk dalam paparan teori dukungan social. Antar teman sebaya memberikan dukungan untuk bisa mengembangkan diri keawah yang lebih baik.

Pemahaman terhadap teori dukungan sosial merupakan hal yang relative karena sifatnya yang multifaceted atau beragam. Dukungan sosial terdiri dari 3 konstruk yakni: dukungan jaringan, dukungan perilaku dan penilaian subjek yang mendukung. Dukungan sosial terjadi secara dinamis antara penerima dan pemberi dukungan. Melihatnya sebagai bentuk interaksi yang saling melengkapi. Dukungan social merupakan interaksi atau hubungan social yang memberikan bantuan secara nyata pada individu yang menjadi kepercayaan pada system social pada terbentuknya kasig saying, kelekatan kepada kelompok social (Dianto., M.Pd., 2017). 
Konselor Sebaya dalam Keterbatasan Waktu Konselor Memberikan Layanan Bimbingan dan Konseling Di Era Pandemi Covid 19

Dukungan tersebut dapat berupa dukungan emosional atau penghargaan, instrumental, informasi, dan companionship (Hasan, Sofy Ariany . Handayani \& Dev), 2014)

Keterbatasan waktu yang dimiliki oleh konselor dalam memberikan layanan bimbingan dan konseling di sekolah. Adapun permasalahannya yakni jumlah rasio konselor dengan peserta didik yang seharusnya 1:150, namun kenyataannya tidak sesuai. Pelakasanaan pemberian layanan BK hanya diberikan pada saat jam BK atau saat istirahat, sehingga dirasa layanan yang diberikan kurang maksimal. Masih kurangnya informasi yang didapatkan oleh siswa terkait layanan Bimbingan dan Konseling. Kondisi pandemic covid 19 yang menuntut dilaksanakannya School from Home membuat konselor kurang maksimal untuk bertatap muka secara lanngsung hanya melaluo media online atau daring

Kondisi school from home memberikan tantangan yang luar biasa kepada guru Bimbingan dan Konseling. Beberapa kendala yang sering dialami selama school from home yakni ketertiban siswa dalam mengikuti pembelajaran serta pengumpulan tugas. Selain itu ada beberapa masalah juga yang muncul yakni jarang mengisi link absensi BK, Kuota/hp terbatas ( untuk kuota tidak semua dapat subsidi dr pemerintah) banyak siswa yang hp nya bergantian dgn ortu, siswa kebanyakan tidak memahami materi yang disampaikan bapak ibu guru pengajar dan siswa sulit berinteraksi dengan teman nya

Sejarah adanya konselor sebaya diawali dengan adanya konsep peer support. Menurut Carter (dalam (Suwarjo, 2008)) Peer support muncul pada tahun 1939 dimana keberadaannya membantu penderita yang kecanduhan alcohol. Penananganan penderita kecanduhan alcohol lebih efektif jika didampingi oleh individu yang sudah berhasil mengatasi kecanduan. Sehingga dari tahun ke tahun konsep teman sebaya atau konselor sebaya ini terus dilanjutkan pada setting dan permasalahan lainnya. Istilah konselor sebaya sampai saat ini masih menimbulkan banyak kesalahan persepsi. Makna konselor sendiri merupakan seorang yang professional dalam artiean sudah menempuh legalitas professional dalam memahami dunia bimbingan dan konseling melalui S1 Bimbingan dan Konseling maupun Program Profesi Konselor (PPK). Terlepas dari adanya kesalahan persepsi tersebut, konselor sebaya hakekatnya ada untuk membantu konselor dalam menjalin relasi atau hubungan kepada konseli-konselinya.

Penggunaan istilah konselor sebaya masih mengalami dilema tersendiri. Penggunaan istilah konselor selama ini mengarah kepada individu yang sudah professional dibidang bimbingan dan konseling melalui pendidikan formal di bidang bimbingan dan konseling maupun pendidikan konselor. Namun, yang terjadi di lapangan penggynaan istilah konselor sebaya di sekolah diharapkan menjadi perpanjangan tangan untuk guru bimbingan dan konseling untuk lebih dekat dengan siswa. Baik terhadap konselor sebaya sendiri maupun dengan siswa lain yang difasilitasi oleh konselor sebaya. Menurut Judy A, T \& H. Dean Gray (dalam (Noviza, 2011)) yang menjelaskan bahwa konselor sebaya sebelum diterjunkan atau dikukuhkan terlabih dahulu mengikuti pelatihan-pelatihan untuk menjadi konselor sebaya agar bisa memberikan bantuan yang baik dalam ranah individual maupun kelompok kepada teman sebayanya yang mengalami kendala dalam perkembangan kepribadiannya.

Adanya konselor sebaya membantu konselor dalam mengatasi permasalahan siswa. Individu lebih mudah terbuka dengan individu lain yang hampir sama dengan mereka baik dalam sisi umur maupun pergaulan. Konselor sebaya bisa menghasilkan dampak positif dan dampak negative bagi individu lain. Dampak positif timbul ketika konselor sebaya mampu merespon dengan baik dan positif terhadap apa yang disampaikan oleh rekannya. Sebaliknya dampak negative timbul ketika konselor sebaya mengeluarkan respon yang negative. Salah satu penelitian memaparakn bahwa dengan adanya konselor sebaya bisa meningkatkan literasi kesehatan mental (Syafitri \& Rahmah, 2021). Konselor sebaya disekolahan ini hanya dibatasi sebagai jembatan guru bimbingan dan konseling dalam memahami apa yang terjadi dalam keseharian siswa dan upaya yang lebih untuk merangkul siswa bisa bersahabat dengan guru bimbingan dan konseling. Hal tersebut sesuai dengan hasil penelitian dari (Teenagers, 2021) yang memaparkan bahawa sebanyak 40\% siswa merasa senang ketika membantu temannya atau ketika menjadi konselor sebaya. Selain itu, (Aditiya et al., 2021) memaparkan konseling sebaya juga bisa diimplementasikan secara daring dimasa pandemic.

Pemilihan konselor sebayapun tidak bisa asal tunjuk atau tanpa kriteria. Pemilihan ini didasarkan pada karakter yang dimiliki oleh siswa. Beberapa karakter yang biasanya diambil yakni seberapa popouler siswa tersebut dalam kelompoknya sehingga nantinya bisa dijadikan model untuk siswa lain. Selain itu, dari sisi intelegenasi atau nilai dalam setiap pelajaran juga dijadikan landasan dalam pemilihan konselor sebaya. Diharapkan siswa bisa memahami bagaimana pentingnya keseimbangan antara prestasi belajar dengan kemampuan untuk bersosialisasi. Kemampuan bersosialisasi ditekankan pada kemampuan untuk 
berkomunikasi yang baik. Komunikasi merupakan hal penting untuk memberikan sugesti kepada teman yang lainnya (Geldard, K., 2005). Sedangkan hasil penelitian dari (Kamore \& Tiego, 2015) memaparkan beberapa kriteria yang bisa digunakan untuk memilih konselor sebaya yakni karakter, kepribadian, prestasi akademik, kepopuleran, disiplin, takut akan Tuhan, dan jenis kelamin.

Menurut Carr (dalam (Suwarjo, 2008)) menjelaskan beberapa alasan perlu adanya konselor sebaya. Beberapa alasan tersebut yakni masih minimnya siswa yang datang ke guru bimbingan dan konseling untuk berkonsultasi. Biasanya siswa lebih sering curhat kepada temannya sebagai penasehat dalam beberapa hal. Masa remaja yang penuh dengan badai psikologis cenderung membawa remaja dalam fase kesepian dan butuh teman yang bisa memahaminya. Pemberdayaan konseling sebaya tidak hanya ada di sekolah, namun di masyarakat implementasi konselor sebaya juga sudah diterapkan, salah satunya penerapan konseling sebaya dilingkungan masayarakt atau masjid dimana permasalahan yang ditangani yakni kebosanan dalam masa pandemic (Sari et al., 2020).

Salah satu pendekatan yang bisa diajarkan kepada konselor sebaya yakni pendekatan Client-Center dari Rogers. Pendekatan ini mengajarkan indvidu atau konselor sebaya untuk mampu berempati, memahami dan menerima secara tidak bersyarat terhadap kondisi individu lain yang sedang berkonsultasi dengannya. Hal tersebut bisa digunakan sebagai landasan unutk membuat nyaman individu lain. Konselor sebaya bisa melakukan konsultasi dengan guru bimbingan dan konseling apabila kesulitan dalam membantu menyelesaikan masalah temannya.

Pembentukan konselor sebaya sudah dilakukan oleh Dinas Pendidikan Surabaya. Tujuan nya untuk melindungi anak dari pengaruh negative akibat pergaulan yang salah di lingkungannya. Selain itu program konselor sebaya ini diadakan di setiap sekolah menengah di lingkungan dinas Pendidikan kota Surabaya untuk lebih mengawasi siswa secara maksimal. Setiap kelas dipilih 2 orang siswa yang menjadi konselor sebaya atau siswa tersebut bersedia mengikuti kegiatan konselor sebaya. Siswa yang terpilih biasanya dari pengurus kelas atau teman teman dikelas mereka yang menonjol. Lalu siswa pilihan tersebut diajarkan cara berkomunikasi dengan teman sebayanya, cara berdiskusi dan lain sebagainya. Setelah mendapatkan pembelajaran cara berkomunikasi, para konselor cilik ini harus mulai mengaplikasikan pada teman dikelas mereka. Biasanya yang terjadi disekolah, jika ada masalah siswa takut menyampaikan secara lansung ke orangtua ataupun guru. Mereka lebih sering mencurahkan isi hatinya melalui media social atau teman. Ketika nanti ada siswa yang curhat ke kader konselor sebaya maka para kader konselor sebaya ini akan mendiskusikan masalah masalah siswa ini ke guru bimbingan konseling (BK) yang nantinya masalah tersebut akan diproses untuk diselesaikan.

Pemanfaatan konselor sebaya juga dilakukan oleh (Putra \& Shofaria, 2020), dimana ketika pandemic covid 19 guru Bimbingan dan Konseling harus melakukan inovasi untuk tetap memberikan layanan kepada siswa. Salah satunya yakni meningkatkan peran teman sebaya. Selain itu, layanan bimbingan dan konseling di masa pandemic juga bisa diarahkan kepada layanan online seperti e-counseling agar tetap bisa memberikan layanan optimal kepada peserta didik ((Permatasari \& Padang, 2021). E-counseling juga biasanya dikenal dengan cyber counselling dimana cyber counselling bisa digunakan juga ketika pandemu covid dan pembelajran dirumah (Pratiwi, 2021). Salah satu teknik yang bisa digunakan untuk layanan cyber counselling yakni Rational EmotifBehavior Therapy yang digunakan untuk mengatasi kecemasan di masa pandemic (Fakhriyani et al., 2021). Guru Bimbingan dan Konseling juga bisa menggunakan sosial media untuk mendukung layanan tetap optimal (Musdalifah, 2021). Dari beberapa kajian ini bisa diambil kesimpulkan bahwa kreatifitas dan pemanfaatan teknologi sangat dibutuhkan guru Bimbingan dan Konseling agar layanan masih bisa diberikan kepada siswa ketika pandemic dan ketika pembelajaran di rumah.

Dari hasil wawancara kepada guru Bimbingan dan Konseling di SMPN 37 Surabaya, layanan Bimbingan dan Konseling ketika pandemic covid 19 dan ketika siswa harus belajar dari rumah mengalami kendala terkait tidak bisanya tatap muka secara langsung untuk mengetahui kondisi siswa. Selain itu juga home visit masih tidak bisa dilakukan. Permasalahan yang sering dialami terkait koordinasi dengan orang tua. Tidak semua orang tua bisa proaktif untuk mendampingi anak dalam mengikuti pembelajaran dari rumah. Ada beberapa orang tua yang harus bekerja diluar rumah dan pengawasan terhadap anak tidak ada. Sehingga guru Bimbingan dan Konseling harus benar-benar memantau siswa dan menghubungi orang tua untuk menanyakan kondisi anak. Kondisi ini menjadi tugas dan karakteristik konselor di masa pandemic (Prawitasari, 2020).

Selain itu, guru Bimbingan dan Konseling juga memanfaatkan adanya konselor sebaya yang sudah dibentuk untuk saling mengingatkan teman sebayanya dalam mengukuti pembelajaran dari rumah. Konselor sebaya menjadi jembatan guru Bimbingan dan Konseling ketika ada kendala yang dihadapi siswa dan bagaimana kondisi siswa ketika pembelajaran daring. Konselor sebaya diberikan tugas oleh konselor untuk 
melaporkan setiap minggu terkait: bagaimana kondisi teman-teman mereka sekelas, permasalahan apa yang sering dialami dan usaha apa yang sudah dilakukan oleh konselor sebaya. Hasil yang disampaikan oleh konselor sebaya memaparkan bahwa siswa banyak yang mengalami lelah psikis dan fisik karena harus setiap hari didepan gadget mereka hampir setiap hari untuk mengikuti pembelajaran. Konselor sebaya melakukan upaya untuk saling mengingatkan kepada temannya terkait presensi dan tugas apa saja yang harus dikerjakan.

Implementasi konselor sebaya di SMPN 37 Surabaya dengan cara penyeleksian yang dilakukan oleh guru bimbingan dan konseling. Ada 36 siswa yang sudah menjadi konselor sebaya di sekolah ini. Pemilihan siswa untuk dijadikan sebagai konselor sebaya didasarkan pada niat atau keinginan yang kuat dari masing-masing individu. Hal tersebut didasarkan bahwa keinginan akan mendorong individu untuk bertindak. Setelah itu, guru bimbingan dan konseling rutin untuk memberikan arahan atau pelatihan terkait bagaimana implementasi pendekatan Client Center Terapi. Setiap bulan dilakukan evaluasi terkait permasalahan apa saja yang sedang dialami oleh siswa secara keseluruhan, kemudian bagaimana peran atau hal-hal yang sudah dilakukan oleh konselor sebaya agar bisa ditindak lanjuti oleh guru bimbingan dan konseling.

\section{Conclusions}

Konselor sebaya dalam implementasinya disekolah mampu membantu konselor atau guru BK dalam keterbatasan masa pandemic covid 19. Pandemic covid 19 ini mengurangi interaksi siswa dengan guru bimbingan dan konseling dari segi bertatapan secara langsung. Interaksi hanya melalui dunia maya. Oleh sebab itu melalui konseling sebaya, guru bimbingan dan konseling mampu memperoleh informasi yang lebih terkait kondisi siswa. Selain itu, konselor sebaya memudahkan guru bimbingan dan konseling untuk memberikan layanan bimbingan dan konseling kepada siswa.

\section{Acknowledgements}

Penulis mengucapkan terima kasih kepada Prodi Bimbingan dan Konseling Universitas PGRI Adi Buana Surabaya dan SMPN 37 Surabaya yang membantu penulis dalam menyelesaikan penelitian dan penyusunan artikel ini.

\section{References}

Aditiya, S., Bimbingan, W., Konseling, D., \& Tinggi, S. (2021). Kualitas Hidup Lansia Di Masa Pandemi Covid-19. KONSELING: Jurnal Ilmiah Penelitian Dan Penerapannya, 2(2), 56-60. https://doi.org/10.31960/konseling.v2i2.816

Dianto. (2017). Profil Dukungan Sosial Orangtua Siswa Di Smp Negeri Kecamatan Batang Kapas Pesisir Selatan. Jurnal Counseling Care, 1(1), 42-51. https://doi.org/10.22202/jcc.2017.v1i1.1994

Fakhriyani, D. V., Sa'idah, I., \& Annajih, M. Z. (2021). Pendekatan REBT Melalui Cyber Counseling untuk Mengatasi Kecemasan di Masa Pandemi COVID-19. Counsellia: Jurnal Bimbingan Dan Konseling, 11(1), 56. https://doi.org/10.25273/counsellia.v11i1.8463

Geldard, K. (2005). Adolescent Peer Counseling.

Hasan, Sofy Ariany. Handayani, M. M., \& Dev), M. P. (Ed \&. (2014). No Title. Jurnal Psikologi Pendidikan Dan Perkembangan, 3(2), 128-135.

https://journal.unair.ac.id/JPPP@table_of_content_53_volume3_nomor2.html

Kamore, S. K., \& Tiego, P. M. (2015). Four pillars of effectiveness of peer counselling programs in Meru South District High Schools, Kenya. International Journal of Humanities and Social Science, 5(2), $254-262$.

Musdalifah, A. (2021). Media Daring Layanan Bk Di Masa Pandemi Covid-19. Ristekdik : Jurnal Bimbingan Dan Konseling, 6(1), 109. https://doi.org/10.31604/ristekdik.2021.v6i1.109-113

Noviza, N. (2011). KONSELING TEMAN SEBAYA (PEER COUNSELING) SUATU INOVASI LAYANAN BIMBINGAN KONSELING DI PERGURUAN TINGGI. WARDAH, 12(1), N BIMBINGAN KONSELING DI PERGURUAN TINGGI. Wardah,. http://jurnal.radenfatah.ac.id/index.php/warda/article/view/213

Permatasari, Y., \& Padang, U. N. (2021). Jurnal Al-Taujih. 7(1), 38-44.

Pratiwi, B. A. I. (2021). Jurnal Realita Bimbingan dan Konseling. 6.

Prawitasari, I. (2020). Implementasi Pelaksanaan Bimbingan Dan Konseling Di Masa Pandemi Covid-19: a Literature Review. Syi'ar: Jurnal Ilmu Komunikasi, Penyuluhan ..., 3(2), 123-130. http://journal.iaisambas.ac.id/index.php/Syiar/article/view/671 
Putra, M. A., \& Shofaria, N. (2020). Inovasi Layanan Bimbingan Dan Konseling Di Masa Pembelajaran Dalam Jaringan Masa Pandemi Covid-19. Bikotetik (Bimbingan Dan Konseling Teori Dan Praktik), 4(2), 55. https://doi.org/10.26740/bikotetik.v4n2.p55-61

Rohmadi, D., Santosa, A. B., \& Adindo, A. W. (2021). GUIDANCE AND COUNSELLING IN THE COVID-19 PANDEMIC PERIOD (Bimbingan Konseling Pada Masa Pandemi Covid-19). XII(1), 74-83.

Saputra, T. A. (2020). Jurnal Bimbingan dan Konseling. Bentuk Kecemasan Dan Resiliensi Mahasiswa Pascasarjana Aceh-Yogyakarta Dalam Menghadapi Pandemi Covid-19, 6(1), 55-61.

Sari, R., Saleh, M. N. I., Rahman, D. N., \& Aisah, A. (2020). Pemberdayaan Remaja Masjid di masa pandemi Covid-19 melalui workshop dan simulasi Konseling Sebaya. Counsellia: Jurnal Bimbingan Dan Konseling, 10(2), 190. https://doi.org/10.25273/counsellia.v10i2.7789

Supriyanto, A., Hartini, S., Irdasari, W. N., Miftahul, A., Oktapiana, S., \& Mumpuni, S. D. (2020). Teacher professional quality: Counselling services with technology in Pandemic Covid-19. Counsellia: Jurnal Bimbingan Dan Konseling, 10(2), 176. https://doi.org/10.25273/counsellia.v10i2.7768

Suwarjo. (2008). KONSELING TEMAN SEBAYA (PEER COUNSELING) UNTUK MENGEMBANGKAN RESILIENSI REMAJA.

Syafitri, D. U., \& Rahmah, L. (2021). Pelatihan Konselor Sebaya Daring Untuk Meningkatkan Literasi Kesehatan Mental Siswa di SMA Islam XY Semarang. Gadjah Mada Journal of Professional Psychology (GamaJPP), 7(1), 39. https://doi.org/10.22146/gamajpp.62299

Taufik. (2021). Implementing Group Counseling to Change Student's Insight Pattern about Learning in the Covid-19 Pandemic. Journal of English Language Teaching and Literature, 2(1), 59-68.

Teenagers, H. (2021). Bagaimana Remaja Menjadi Peer-Counselor di Masa Pandemi ? 1(1), 32-44. 